\title{
Direct detection of Helicobacter pylori from biopsies of patients in Lagos, Nigeria using real-time PCR - a pilot study
}

\author{
A. Ajayi ${ }^{1}$, T. Jolaiya ${ }^{2}$ and S. I. Smith ${ }^{1,3^{*}}$
}

\begin{abstract}
Objective: Prompt diagnosis of Helicobacter pylori infection is essential for proper treatment and eradication of the pathogen because prolonged infection could lead to gastric cancer. Sensitive and cost effective diagnostic methods are key to guiding treatment options that will reduce mortality. This study was aimed at detecting H. pylori from biopsies of peptic ulcer patients. Real-time PCR using TaqMan and EvaGreen assays targeting 16S rRNA and ureA genes were used to detect $H$. pylori DNA extracted from 40 biopsy samples comprising 20 biopsies obtained from the antrum and 20 from the corpus of 20 patients undergoing endoscopy for duodenal ulcer investigation in Lagos, Nigeria.

Results: H. pylori was detected in $80 \%$ of the biopsy samples by combined cycle threshold $\left(C_{t}\right)$ and melting temperature $\left(T_{m}\right)$ values. Mean $C_{t}$ value for ureA gene ranged from 21.40 to 37.53 and 22.71 to 35.44 for 16 SrRNA gene. Average melting temperatures $\left(T_{m}\right)$ of 81.57 and $82.90^{\circ} \mathrm{C}$ among amplicons of ureA and $16 \mathrm{~S}$ rRNA were observed respectively. H. pylori DNA was generally detected in biopsies collected from antrum and corpus. Real-time PCR in the diagnosis of H. pylori can be considered a simple, low cost and efficient alternative or addition to the gold standard.
\end{abstract}

Keywords: Helicobacter pylori, Diagnosis, Real-time PCR, Biopsy, Ulcer

\section{Introduction}

Gastritis, duodenal ulcer, gastric ulcer and in some cases gastric cancers are hallmarks of Helicobacter pylori infection. H. pylori is a Gram negative bacterium that colonize $50 \%$ of the stomach of humans globally [1,2]. H. pylori possess several virulence factors including the production of urease that enable it successfully colonize the stomach where it can persist for a long period of time. The pathogen has been classified as a type 1 carcinogen hence, its persistence in infection without eradication may lead to chronic gastritis, mucosa-associated lymphoid tissue (MALT) lymphoma and gastric cancer [3-5]. H. pylori is a fastidious bacterium making it very

\footnotetext{
*Correspondence: stellaismith@yahoo.com

1 Department of Molecular Biology and Biotechnology, Nigerian Institute

of Medical Research, Yaba, Lagos, Nigeria

Full list of author information is available at the end of the article
}

delicate to culture. Although non-invasive methods of detecting $H$. pylori exist [6], culture remains the gold standard which requires competence and a lot of materials making it expensive. Detection of $H$. pylori DNA directly from biopsies by molecular methods especially PCR have been reported by several workers $[7,8]$ with excellent sensitivity and specificity. In Nigeria, the use of conventional PCR in the detection of $H$. pylori DNA from biopsies have been demonstrated $[9,10]$. However, the use of real-time PCR in the detection of H. pylori in biopsies have not been explored in the country. The purpose of this study was to detect $H$. pylori DNA isolated from gastric biopsies (corpus and antrum) obtained from patients in Lagos Nigeria.

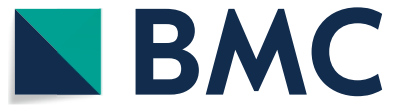

(c) The Author(s) 2021. This article is licensed under a Creative Commons Attribution 4.0 International License, which permits use, sharing, adaptation, distribution and reproduction in any medium or format, as long as you give appropriate credit to the original author(s) and the source, provide a link to the Creative Commons licence, and indicate if changes were made. The images or other third party material in this article are included in the article's Creative Commons licence, unless indicated otherwise in a credit line to the material. If material is not included in the article's Creative Commons licence and your intended use is not permitted by statutory regulation or exceeds the permitted use, you will need to obtain permission directly from the copyright holder. To view a copy of this licence, visit http://creativeco mmons.org/licenses/by/4.0/. The Creative Commons Public Domain Dedication waiver (http://creativecommons.org/publicdomain/ zero/1.0/) applies to the data made available in this article, unless otherwise stated in a credit line to the data. 


\section{Main text}

Samples used for this study were biopsies obtained from 20 patients undergoing endoscopy for duodenal ulcer investigation in Lagos, Nigeria. A total of 40 biopsies comprising 20 obtained from the corpus and 20 from the antrum were analysed.

\section{Methodology}

DNA was extracted from gastric biopsies (corpus and antrum) and $H$. pylori reference strain $J 99$ (NCBI:txid85963) with QIAamp DNA Mini Kit (Qiagen, Hilden, Germany) according to manufacturer's instructions.

Detection of $H$. pylori was done by singleplex realtime PCR amplifying fragments of $16 \mathrm{~S}$ rRNA and ure $A$ genes using specific primers and probes listed in Additional file 1: Table S1 with slight modification (quencher of probes was Black Hole Quencher (BHQ) instead of TAMARA). Detection of $H$. pylori targeting the two set of primers was first validated by using $H$. pylori DNA extracted from reference $H$. pylori strain J99 (NCBI:txid85963) and DNA extracted from Salmonella Typhimurium ATCC 14028, Staphylococcus aureus ATCC 29213, Pseudomonas aeruginosa ATCC 27853 and Escherichia coli ATCC 29522. A standard curve of the assay was determined as serial dilution of DNA from $H$. pylori $\mathrm{J99}$ positive control which was prepared with final concentration of $10^{1}-10^{5}$; reactions were ran in triplicate. The curve was determined by plotting threshold cycle $(\mathrm{Ct})$ value against count of log DNA copies from which positive samples were considered as amplification plot with $\mathrm{Ct}$ values $<40$. Real-time PCR was carried out in a StepOne Real-Time PCR system (Applied Biosystem, Singapore). A $20 \mu \mathrm{L}$ reaction was used in both the TaqMan and EvaGreen assays which contained $11.2 \mu \mathrm{L}$ nuclease free water, $4 \mu \mathrm{L}$ of Solis Biodyne $5 \times \mathrm{HOT} \mathrm{FIREPol}^{\circledR}$ Probe qPCR Mix Plus (for TaqMan assay) and 5X HOT FIREPol ${ }^{\circledR}$ EvaGreen Supermix (Solis Biodyne Tartu, Estonia), $0.4 \mu \mathrm{L}(10 \mu \mathrm{M})$ each of both forward and reverse primers and $4 \mu \mathrm{L}$ of $(20 \mathrm{ng} / \mu \mathrm{L})$ DNA template. PCR cycling parameters for the EvaGreen assay were an initial denaturation at $95{ }^{\circ} \mathrm{C}$ for $12 \mathrm{~min}$ and 40 cycles of denaturation at $95{ }^{\circ} \mathrm{C}$ for $15 \mathrm{~s}$, annealing for $1 \mathrm{~min}$ at $54{ }^{\circ} \mathrm{C}$ for $16 \mathrm{~S}$ rRNA gene, $55{ }^{\circ} \mathrm{C}$ annealing temperature for ureA gene, extension at $72{ }^{\circ} \mathrm{C}$ for $20 \mathrm{~s}$ and a melting step. While PCR cycling parameters for the TaqMan assay were initial denaturation at $95{ }^{\circ} \mathrm{C}$ for $12 \mathrm{~min}$, denaturation at $95{ }^{\circ} \mathrm{C}$ for $15 \mathrm{~s}$, annealing/elongation at $54{ }^{\circ} \mathrm{C}$ for $16 \mathrm{~S}$ rRNA gene and $55^{\circ} \mathrm{C}$ for ure $A$ gene both for $1 \mathrm{~min}$. After which amplification results were analysed with StepOne Software v.23 and GraphPad Prism software version 5 (GraphPad Software, LA Jolla, CA, USA).

\section{Results}

Real-time PCR assay for the detection of $H$. pylori from genomic DNA extracted from biopsies and extracted DNA from $H$. pylori reference strain $J 99$ (NCBI:txid85963) showed amplification curves for all targeted genes (ureA and 16S rRNA). However, there was no amplification with DNA extracted from other bacterial pathogens (Salmonella Typhimurium ATCC 14028, Staphylococcus aureus ATCC 29,213, Pseudomonas aeruginosa ATCC and Escherichia coli ATCC 29522) as shown in Fig. 1 indicating specificity of primers and probes used.

Eighty percent of the samples were positive for $H$. pylori. However, $H$. pylori was detected in the antrum of two patients but was not detected in the corpus. The reverse was observed in a third patient in which $H$. pylori was detected in the corpus but absent in the antrum. The logarithm of the number of $H$. pylori DNA copies in the samples correlated largely well with the ureA and $16 \mathrm{~S}$ rRNA threshold cycle $\left(C_{t}\right)$ values which is a representation of the DNA copy number in the PCR reaction. Mean $C_{t}$ value for ureA gene ranged from Mean $\pm \mathrm{SD}$ : $21.40 \pm 15.14$ to $37.53 \pm 0.89$ and for $16 \mathrm{~S}$ rRNA gene Mean \pm SD: $22.71 \pm 0.12$ to $35.44 \pm 0.87$ as shown in Figs. 2 and 3. Correlation coefficient $\left(R^{2}\right)$ and amplification efficiency $(E)$ was $0.994 / 90.35 \%, 0.997 / 97.94 \%$ for ure $A$ and $16 \mathrm{~S}$ rRNA respectively.

The intercalating chemistry EvaGreen used showed smooth melting curve (Additional file 2: Figure S1) and average melting temperatures $\left(T_{m}\right)$ of 81.57 and $82.90{ }^{\circ} \mathrm{C}$ among amplicons of $u r e A$ and $16 \mathrm{~S}$ rRNA respectively.

\section{Discussion}

Helicobacter pylori infection remains a major public health issue around the world. The prevalence of $H$. pylori infection in Nigeria is estimated at about $87.7 \%$ which indicates a high infection burden [1] making prompt, accurate and efficient diagnosis imperative. The PCR results for the detection of $H$. pylori from biopsies and other bacterial pathogens indicated the reliability of using the $H$. pylori ure $A$ and $16 \mathrm{~S}$ rRNA primer set in this study. Eighty percent of the samples were positive for $H$. pylori with the assay showing great efficiency in detecting small quantities of $H$. pylori DNA. Correlation coefficient $\left(R^{2}\right)$ and amplification efficiency $(E)$ of both ure $A$ $(0.994 / 90.35 \%)$ and $16 \mathrm{~S}$ rRNA $(0.997 / 97.94 \%)$ proved to be good. Hence it could be inferred that these targets had great specificity since all $H$. pylori strains harbour the gene that encodes urease. In the study of Ramı'rezLa'zaro et al. [11], they suggested the combination of both 16S rRNA and ureA genes in the diagnosis of $H$. pylori from biopsies for better sensitivity. However, in the 

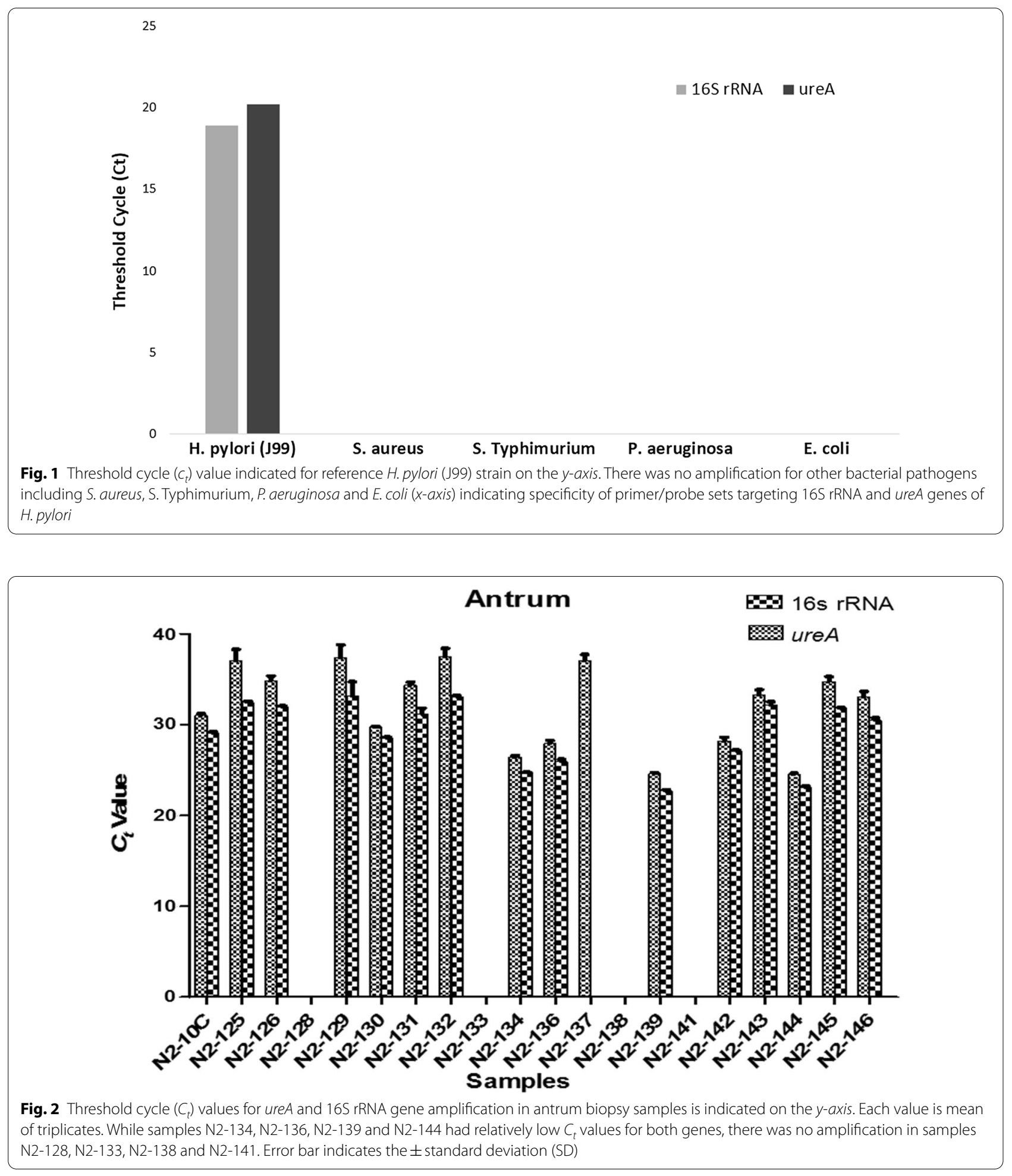

study by Beer-Davidson et al. [12] in which they reported the detection of $H$. pylori in stool samples of children in Israel using real-time PCR targeting urease gene, it was observed that the gene gave a clearer amplification curve compared to $16 \mathrm{~S}$ rRNA gene. In this study, the mean temperature separation between ureA $\left(81.57^{\circ} \mathrm{C}\right)$ and $16 \mathrm{~S}$ rRNA $\left(82.90{ }^{\circ} \mathrm{C}\right)$ was $1.33{ }^{\circ} \mathrm{C}$. Thus it could be asserted that amplification products of ure $A$ gene could easily be 


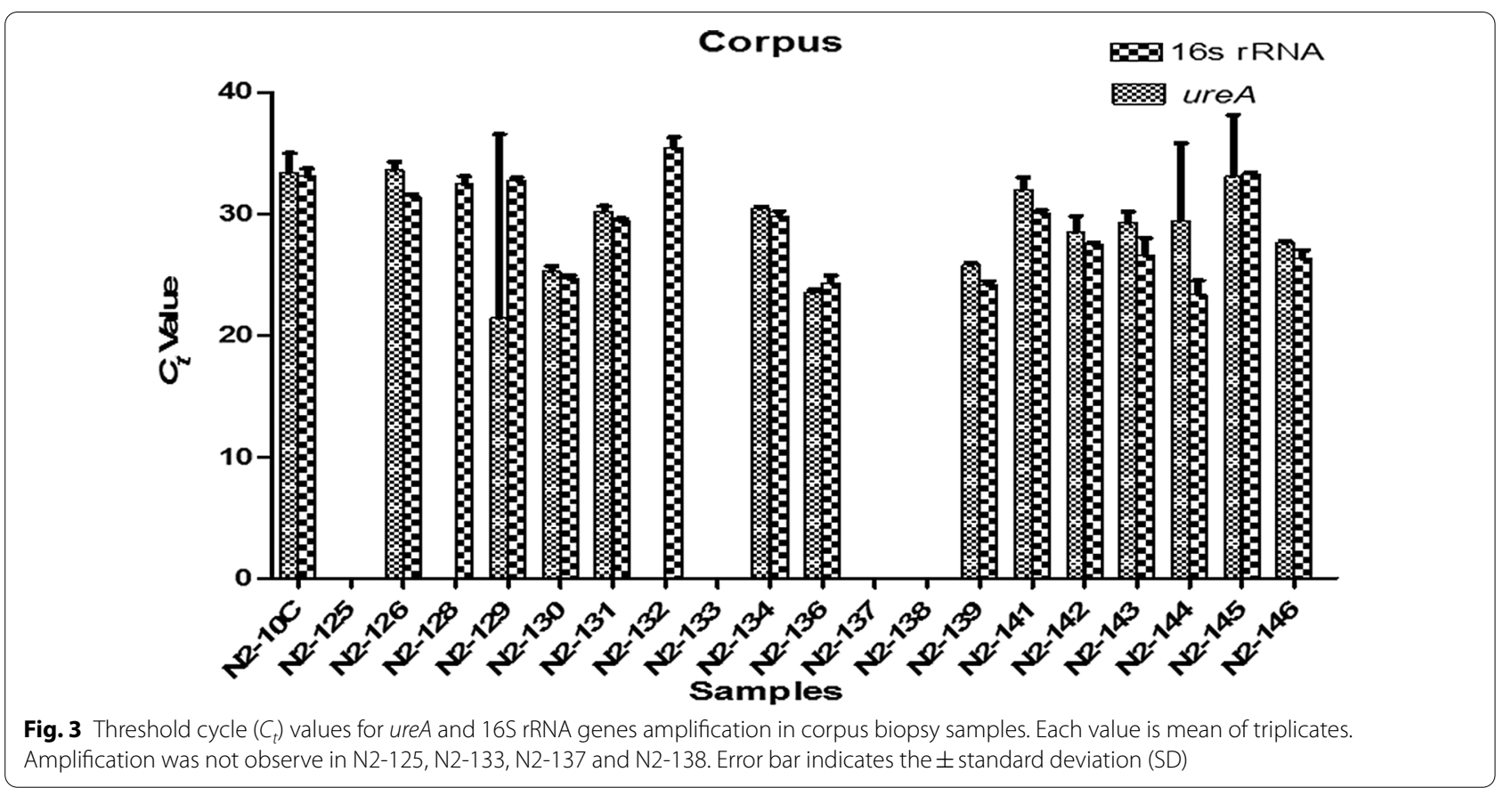

distinguished from 16S rRNA even in a multiplex qPCR reaction. Contreras et al. [13] reported a melting temperature range between 57.0 and $57.4{ }^{\circ} \mathrm{C}$ that enabled them detect $16 \mathrm{~S}$ rRNA single mutation associated with antibiotic resistance in $H$. pylori strains isolated from biopsies in Venezuela compared to a higher $\mathrm{T}_{\mathrm{m}}$ that was observed in wild type strains. The detection of $H$. pylori in biopsies collected from the antrum and corpus is widely reported. Pichon et al. [14], reported the detection of $H$. pylori in both biopsies of antrum and corpus obtained from patients with $H$. pylori infection. However, in this present study there was zero detection of $H$. pylori in the corpus of two patients in which $H$. pylori was detected in their antrum biopsy samples. Similarly, in one patient, H. pylori was detected in corpus biopsy but absent in the antrum. Palamides et al. [15] reported similar findings in which $H$. pylori was detected in biopsies from either antrum or corpus of some patients using conventional PCR. This suggest that there are variations in the distribution of $H$. pylori in the gut of $H$. pylori infected patients. Lan et al. [16] reported in their study that corpus biopsy enhances the detection of $H$. pylori infection. Similarly, Latif et al. [17] opined that in addition to antral biopsy, corpus biopsy increases the sensitivity in the detection of $H$. pylori infection.

\section{Conclusion}

Real-time PCR in the diagnosis of $H$. pylori can be considered an alternative or in addition to the gold standard and including histology since it relies on the detection of DNA isolated from biopsies and not necessarily viable bacteria coupled with its competitive cost [11]. Furthermore, direct detection of $H$. pylori from biopsies can circumvent the difficulty and extended time lapse encountered with culture.

\section{Limitation of study}

It would be difficult to make far reaching conclusion as the number of samples in this study are few and other diagnostic methods such as histology and culture were not evaluated alongside real-time PCR. Hence, future study should increase the number of samples and evaluate other diagnostic methods alongside.

\section{Abbreviations}

ATCC: American Type Culture Collection; BHQ: Black Hole Quencher; Ct: Cycle threshold; MALT: Mucosa-associated Lymphoid Tissue; Tm: Melting Temperature.

\section{Supplementary Information}

The online version contains supplementary material available at https://doi. org/10.1186/s13104-021-05505-y.

Additional file 1: Table S1. Primers used in the detection of H. pylori by TaqMan and EvaGreen qPCR assay.

Additional file 2: Figure S1. Melting curve of EvaGreen real-time PCR targeting a 16SrRNA $\mathbf{b}$ ureA. Melting peaks were derived by the plot of derivative reporter $(-R)$ against temperature $\left({ }^{\circ} \mathrm{C}\right)$ 


\section{Acknowledgements}

SIS wishes to acknowledge the Alexander von Humboldt Foundation for the donation of the StepOne Real-Time PCR System.

\section{Authors' contributions}

Conception and design: SSI; Laboratory experiment: AA JT; Result Analysis and manuscript writing/review: AA, JT, SSI. All authors read and approved the final manuscript.

\section{Funding}

None.

\section{Availability of data and materials}

The datasets used and/or analysed during the current study available from the corresponding author on reasonable request.

\section{Declarations}

\section{Ethical approval and consent to participate}

Written consent was obtained from participants before they will recruited for the study and ethical approval was obtained from Institutional Review Board of the Nigerian Institute of Medical Research with number IORG0002656.

\section{Consent for publication}

Not applicable.

\section{Competing interests}

There is no conflict of interest.

\section{Author details}

1 Department of Molecular Biology and Biotechnology, Nigerian Institute of Medical Research, Yaba, Lagos, Nigeria. ${ }^{2}$ Department of Microbiology, University of Lagos, Lagos, Nigeria. ${ }^{3}$ Mountain Top University, Makogi Oba, Ogun, Nigeria.

\section{Received: 11 December 2020 Accepted: 27 February 2021}

Published online: 09 March 2021

\section{References}

1. Smith S, Fowora M, Pellicano R. Infections with Helicobacter pylori and challenges encountered in Africa. World J Gastroenterol. 2019;25(25):3183-95.

2. Haddadi M-H, Negahdari B, Asadolahi R, Bazargani A. Helicobacter pylori antibiotic resistance and correlation with cagA motifs and homB gene. Postgrad Med. 2020. https://doi.org/10.1080/00325481.2020.1753406.

3. Syahniar R, Wahid MH, Syam AF, Yasmon A. Detecting the Helicobacter pylori 165 rRNA gene in dyspepsia patients using real-time PCR. Acta Med Indones-Indones J Intern Med. 2019;51(1):34-40.

4. Vazirzadeh J, Falahi J, Moghim S, Narimani T, Rafiei R, Karbasizadeh V. Molecular assessment of resistance to clarithromycin in Helicobacter pylori strains isolated from patients with dyspepsia by fluorescent in situ hybridization in the center of Iran. BioMed Res Int. 2020;2304173:1-7.
5. Hamidi S, Badmasti F, Heravi FS, Safapoor MH, Tabrizi AMA, Ghorbani M, et al. Antibiotic resistance and clonal relatedness of Helicobacter pylori strains isolated from stomach biopsy specimens in northeast of Iran. Helicobacter. 2020;00:e12684.

6. Wang YK, Kuo FC, Liu CJ, et al. Diagnosis of Helicobacter pylori infection: current options and developments. World J Gastroenterol. 2015;21(40):11221-35.

7. Bénéjat L, Ducournau A, Lehours P, Mégraud F. Real-time PCR for Helicobacter pyloridiagnosis. The best tools available. Helicobacter. 2018. https ://doi.org/10.1111/hel.12512.

8. Van den Poel B, Gils S, Micalessi I, Carton S, Christiaens P, Cuyle P-J, Moons V, Van Olmen G, Smismans A, Bourgain C, Bossuyt P, Frans J. Molecular detection of Helicobacter pylori and clarithromycin resistance in gastric biopsies: a prospective evaluation of RIDA ${ }^{\circledR}$ GENE Helicobacter pylori assay. Acta Clin Belg. 2019. https://doi.org/10.1080/17843286.2019.1685741.

9. Smith SI, Oyedeji KS, Arigbabu AO, Cantet F, Megraud F, Ojo OO, Uwaifo $A O$, et al. Comparison of three PCR methods for detection of Helicobacter pylori DNA and detection of cagA gene in gastric biopsy specimens. World J Gastroenterol. 2004;10(13):1958-60.

10. Smith SI, Fowora MA, Otegbayo JA, Abdulkareem FB, Omonigbehin EA, Adegboyega A, et al. Comparison of PCR with other diagnostic techniques for the detection of $\mathrm{H}$. pylori infection in patients presenting with gastroduodenal symptons in Nigeria. Int J Mol Epidemiol Genet. 2011:2(2):178-84.

11. Ramı'rez-La"zaro MJ, Lario S, Casalots A, Sanfeliu E, Boix L, Garcla-Iglesias $P$, et al. Real-time PCR improves Helicobacter pylori detection in patients with peptic ulcer bleeding. PLoS ONE. 2011;6(5):e20009.

12. Beer-Davidson G, Hindiyeh M, Muhsen K. Detection of Helicobacter pyloriin stool samples of young children using real-time polymerase chain reaction. Helicobacter. 2017. https://doi.org/10.1111/hel.12450.

13. Contreras M, Benejat L, Mujica H, Peña J, García-Amado M-A, Michelangeli F, et al. Real-time PCR detection of a 16S rRNA single mutation of Helicobacter pylori isolates associated with reduced susceptibility and resistance to tetracycline in the gastroesophageal mucosa of individual hosts. J Med Microbiol. 2019:68:1287-91.

14. Pichon M, Tran CT, Motillon G, Debiais C, Gautier S, Aballea M, et al. Where to biopsy to detect Helicobacter pylori and how many biopsies are needed to detect antibiotic resistance in a human stomach. J Clin Med. 2020;9:2812. https://doi.org/10.3390/jcm9092812.

15. Palamides $P$, Jolaiya $T$, Idowu $A$, Loell E, Onyekwere $C$, Ugiagbe $R$, et al. Helicobacter pylori patient isolates from South Africa and Nigeria differ in virulence factor pathogenicity profile and associated gastric disease outcome. Sci Rep. 2020;10:11409.

16. Lan H-C, Chen T-S, Li AF-Y, Chang F-Y, Lin H-C. Additional corpus biopsy enhances the detection of Helicobacter pylori infection in a background of gastritis with atrophy. BMC Gastroenterol. 2012;12:182.

17. Latif MEA, Shahin R, Abdrabou RM, Shawqy A, El-Ghadban HM, Arafa M, et al. Value of additional corpus biopsy for diagnosis of Helicobacter pylori in atrophic gastritis. J Gastro Hepato Dis. 2016;2(1):108.

\section{Publisher's Note}

Springer Nature remains neutral with regard to jurisdictional claims in published maps and institutional affiliations.

\footnotetext{
Ready to submit your research? Choose BMC and benefit from:

- fast, convenient online submission

- thorough peer review by experienced researchers in your field

- rapid publication on acceptance

- support for research data, including large and complex data types

- gold Open Access which fosters wider collaboration and increased citations

- maximum visibility for your research: over $100 \mathrm{M}$ website views per year
}

At BMC, research is always in progress.

Learn more biomedcentral.com/submissions 